\title{
AMD3100/CXCR4 inhibitor
}

\section{Erik De Clercq*}

Department of Microbiology and Immunology, Rega Institute for Medical Research, KU Leuven, Leuven, Belgium

${ }^{*}$ Correspondence: erik.declercq@rega.kuleuven.be

\section{Edited by:}

Bernhard Moser, Cardiff University, UK

Reviewed by:

Hal Broxmeyer, Indiana University School of Medicine, USA

Sara M. Rankin, Imperial College London, UK

Keywords: anti-HIV, CXCR4, bicyclam, AMD3100, stem cell

The original bicyclam, JM1657 (JM standing for Johnson Matthey) was discovered as a contaminant in a commercial preparation of monocyclams when evaluated for their anti-HIV activity. The original compound, in which the cyclam rings were tethered by a C-C linkage could not be re-synthesized but launched the synthesis of new bicyclams in which the cyclam moieties were linked through an aliphatic bridge: one of these derivatives, i.e., JM2763, exhibited an anti-HIV activity similar to that of JM1657 (1). The compound was postulated to interfere with the uncoating of HIV, a stage in the replicative cycle of HIV, which was (and still is) ill-defined. A quantum jump in anti-HIV potency was achieved with the synthesis of AMD3100 (AMD standing for AnorMeD) (which was originally called JM3100), where the two cyclam rings are tethered by an aromatic bridge (Figure 1A) (2). The compound was active against HIV in the low nanomolar concentration range and generated considerable commercial interest, although its precise mechanism of action remained enigmatic $(3,4)$. Finally, the viral glycoprotein gp120 was identified as the molecular target of AMD3100 (5). It appeared to be an indirect target. The direct target was CXCR4, with which gp 120 has to interact for HIV to enter the cells. AMD3100 was shown to specifically antagonize CXCR4, and thus to block the entry of the T-lymphotropic HIV strains (6-8). AMD3100 appears to be a highly specific inhibitor of CXCR4 (9): it only blocks, as measured by the $\mathrm{Ca}^{++}$flux, the signal pathway from CXCR4 (Figure 1B) and not that of any other receptor for either CXC- or<smiles>CCCNCCCNCCCNCCCNCCCN1CCCCNCCCNCCC1</smiles>

$8 \mathrm{HCl} 2 \mathrm{H}_{2} \mathrm{O}$

C

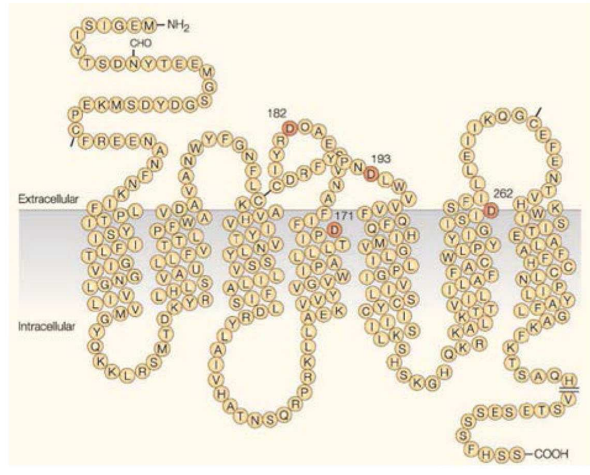

B

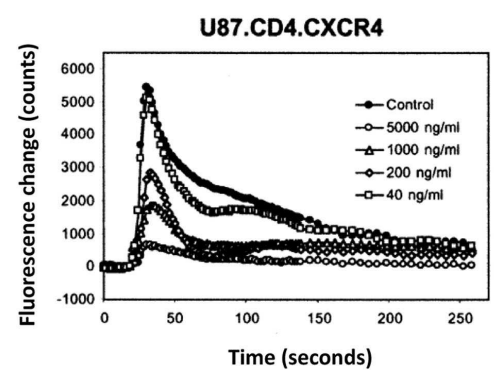

D

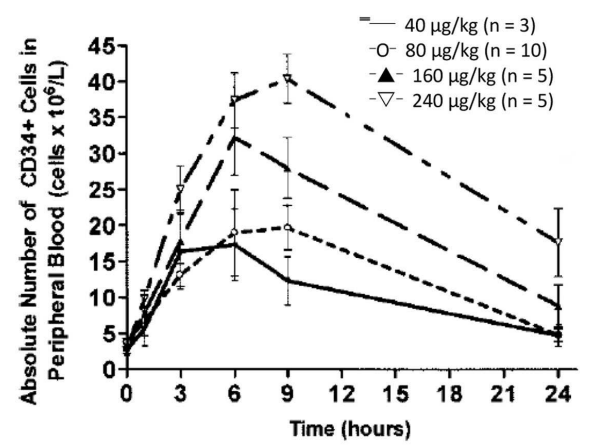

FIGURE 1 | (A) Structure of AMD3100. (B) Inhibitory effect of AMD3100 on $\mathrm{Ca}^{++}$flux in CXCR4 transfected cells (9). (C) The CXCR4 receptor. Crucial aspartic acid residues at positions 171, 182, 193, and
262 in the interaction of CXCR4 with AMD3100 are indicated (11). (D) Mobilization of $\mathrm{CD}_{3} 4^{+}$hematopoietic stem cells (HSCs) by AMD3100 (12). 
C-C-chemokines (9). Certain aspartic acid residues play an essential role in the interaction of CXCR4 with AMD3100 (Figure 1C) $(10,11)$.

Within the scope of the potential clinical use of AMD3100 for the treatment of HIV infections, initial phase 1 clinical trials were initiated (13). These studies revealed an increase in the white blood cell (WBC) counts peaking at about 8$10 \mathrm{~h}$ after (subcutaneous) injection. These WBCs contained hematopoietic stem cells (HSCs) carrying the CD34 marker (12) (Figure 1D). In fact, the first proof-ofprinciple that AMD3100 could mobilize hematopoietic stem and progenitor cells was provided by Broxmeyer et al. (14). Thus, the concept was born that AMD3100 (now also called plerixafor or Mozobil ${ }^{\circledR}$ ) could function as a mobilizer of HSCs. This mobilization is clearly based on the interaction of AMD3100 with CXCR4. CXCR4 is normally the receptor for the chemokine SDF-1 (now called CXCL12), which is responsible for the "homing" of the HSCs in the bone marrow. Under the influence of AMD3100, the HSCs leave the bone marrow to enter the bloodstream where they can be collected and subsequently used for autologous transplantation. In December 2008, Mozobil ${ }^{\circledR}$ was approved by the FDA for this indication in patients with non-Hodgkin's lymphoma or multiple myeloma. It is used in combination with granulocyte-colony stimulating factor (G-CSF) [for review, see Keating (15)]. For prescribing information, see Ref. (16).

AMD3100 was not further developed for the treatment of HIV infections essentially because of two reasons: (i) AMD3100 was not effective against the M-tropic CCR5 HIV strains, a problem that could be circumvented by the concomitant (oral) use of a CCR5 antagonist, maraviroc (Selzentry ${ }^{\circledR}$ ), and (ii) it had to be injected subcutaneously, as it was not orally bioavailable. Subcutaneous injection is indeed a problem for longterm administration, and Fuzeon ${ }^{\circledR}$ (enfuvirtide) is the only anti-HIV drug out of more than 25 , which has to be administered by injection, and, therefore, not widely used. Attempts to increase the spectrum of AMD3100 derivatives toward M-tropic HIV strains and, particularly, to increase their oral bioavailability led to the synthesis of AMD3465 (17), AMD11070 (18), and various other compounds (19-21), which, however, were not further developed as clinical candidates for treatment of HIV infections. Related CXCR4 antagonists such as KRH-1636 (22), KRH-3955 (23), and T140 analogs (24) were described by Naoki Yamamoto and his colleagues in Japan.

\section{REFERENCES}

1. De Clercq E, Yamamoto N, Pauwels R, Baba M, Schols D, Nakashima H, et al. Potent and selective inhibition of human immunodeficiency virus (HIV)-1 and HIV-2 replication by a class of bicyclams interacting with a viral uncoating event. Proc Natl Acad Sci U S A (1992) 89:5286-90. doi:10.1073/pnas.89.12.5286

2. De Clercq E, Yamamoto N, Pauwels R, Balzarini J, Witvrouw M, De Vreese K, et al. Highly potent and selective inhibition of human immunodeficiency virus by the bicyclam derivative JM3100. Antimicrob Agents Chemother (1994) 38:668-74. doi:10.1128/AAC.38.4.668

3. De Vreese K, Reymen D, Griffin P, Steinkasserer A, Werner G, Bridger GJ, et al. The bicyclams, a new class of potent human immunodeficiency virus inhibitors, block viral entry after binding. Antiviral Res (1996) 29:209-19. doi:10.1016/0166-3542(95) 00837-3

4. Esté JA, De Vreese K, Witvrouw M, Schmit JC, Vandamme AM, Anné J, et al. Antiviral activity of the bicyclam derivative JM3100 against drug-resistant strains of human immunodeficiency virus type 1. Antiviral Res (1996) 29:297-307. doi:10.1016/ 0166-3542(95)00936- 1

5. De Vreese K, Kofler-Mongold V, Leutgeb C, Weber V, Vermeire K, Schacht S, et al. The molecular target of bicyclams, potent inhibitors of human immunodeficiency virus replication. J Virol (1996) 70:689-96.

6. Schols D, Struyf S, Van Damme J, Esté JA, Henson G, De Clercq E. Inhibition of T-tropic HIV strains by selective antagonization of the chemokine receptor CXCR4. J Exp Med (1997) 186:1383-8. doi:10.1084/jem.186.8.1383

7. Schols D, Esté JA, Henson G, De Clercq E. Bicyclams, a class of potent anti-HIV agents, are targeted at the HIV coreceptor fusin/CXCR4. Antiviral Res (1997) 35:147-56. doi:10.1016/ S0166-3542(97)00025-9

8. Donzella GA, Schols D, Lin SW, Esté JA, Nagashima KA, Maddon PJ, et al. AMD3100, a small-molecule inhibitor of HIV-1 entry via the CXCR4 coreceptor. Nat Med (1998) 4:72-7. doi:10.1038/ nm0198-072

9. Hatse S, Princen K, Bridger G, De Clercq E, Schols D. Chemokine receptor inhibition by AMD3100 is strictly confined to CXCR4. FEBS Lett (2002) 527:255-62. doi:10.1016/S0014-5793(02)03143-5

10. Gerlach LO, Skerlj RT, Bridger GJ, Schwartz TW. Molecular interactions of cyclam and bicyclam non-peptide antagonists with the CXCR4 chemokine receptor. J Biol Chem (2001) 276:14153-60. doi:10.1074/jbc.M010429200

11. Hatse S, Princen K, Gerlach LO, Bridger G, Henson G, De Clercq E, et al. Mutation of Asp(171) and Asp(262) of the chemokine receptor CXCR4 impairs its coreceptor function for human immunodeficiency virus- 1 entry and abrogates the antagonistic activity of AMD3100. Mol Pharmacol (2001) 60:164-73. doi:10.1124/mol.60.1.164

12. Liles WC, Broxmeyer HE, Rodger E, Wood B, Hübel $\mathrm{K}$, Cooper S, et al. Mobilization of hematopoietic progenitor cells in healthy volunteers by AMD3100, a CXCR4 antagonist. Blood (2003) 102:2728-30. doi:10.1182/blood-2003-02-0663

13. Hendrix CW, Flexner C, MacFarland RT, Giandomenico C, Fuchs EJ, Redpath E, et al. Pharmacokinetics and safety of AMD-3100, a novel antagonist of the CXCR-4 chemokine receptor, in human volunteers. Antimicrob Agents Chemother (2000) 44:1667-73. doi:10.1128/AAC.44.6.16671673.2000

14. Broxmeyer HE, Orschell CM, Clapp DW, Hangoc G, Cooper S, Plett PA, et al. Rapid mobilization of murine and human hematopoietic stem and progenitor cells with AMD3100, a CXCR4 antagonist. J Exp Med (2005) 201:1307-18. doi:10.1084/jem. 20041385

15. Keating GM. Plerixafor: a review of its use in stem-cell mobilization in patients with lymphoma or multiple myeloma. Drugs (2011) 71:1623-47. doi:10.2165/11206040-000000000-00000

16. Available from: http://products.sanofi.us/Mozobil/ mozobil.html

17. Bridger GJ, Skerlj RT, Hernandez-Abad PE, Bogucki DE, Wang Z, Zhou Y, et al. Synthesis and structure-activity relationships of azamacrocyclic C-X-C chemokine receptor 4 antagonists: analogues containing a single azamacrocyclic ring are potent inhibitors of T-cell tropic (X4) HIV1 replication. J Med Chem (2010) 53:1250-60. doi:10.1021/jm901530b

18. Skerlj RT, Bridger GJ, Kaller A, McEachern EJ, Crawford JB, Zhou Y, et al. Discovery of novel small molecule orally bioavailable C-X-C chemokine receptor 4 antagonists that are potent inhibitors of T-tropic (X4) HIV-1 replication. J Med Chem (2010) 53:3376-88. doi:10.1021/ jm $100073 \mathrm{~m}$

19. Skerlj R, Bridger G, McEachern E, Harwig C, Smith C, Wilson T, et al. Synthesis and SAR of novel CXCR4 antagonists that are potent inhibitors of T tropic (X4) HIV-1 replication. Bioorg Med Chem Lett (2011) 21:262-6. doi:10.1016/j.bmcl.2010.11. 023

20. Skerlj R, Bridger G, McEachern E, Harwig C, Smith C, Kaller A, et al. Design of novel CXCR4 antagonists that are potent inhibitors of T-tropic (X4) HIV-1 replication. Bioorg Med Chem Lett (2011) 21:1313-8. doi:10.1016/j.bmcl.2011.01.021

21. Khan A, Nicholson G, Greenman J, Madden L, McRobbie G, Pannecouque C, et al. Binding optimization through coordination chemistry: CXCR4 chemokine receptor antagonists from ultrarigid metal complexes. J Am Chem Soc (2009) 131:3416-7. doi:10.1021/ja807921k

22. Ichiyama K, Yokoyama-Kumakura S, Tanaka Y, Tanaka R, Hirose K, Bannai K, et al. A duodenally absorbable CXC chemokine receptor 4 antagonist, KRH-1636, exhibits a potent and selective antiHIV-1 activity. Proc Natl Acad Sci U S A (2003) 100:4185-90. doi:10.1073/pnas.0630420100

23. Murakami T, Kumakura S, Yamazaki T, Tanaka $\mathrm{R}$, Hamatake $\mathrm{M}$, Okuma $\mathrm{K}$, et al. The novel 
CXCR4 antagonist KRH-3955 is an orally bioavailable and extremely potent inhibitor of human immunodeficiency virus type 1 infection: comparative studies with AMD3100. Antimicrob Agents Chemother (2009) 53:2940-8. doi:10.1128/AAC. 01727-08

24. Tamamura H, Tsutsumi H, Masuno H, Mizokami S, Hiramatsu K, Wang Z, et al. Development of a linear type of low molecular weight CXCR4 antagonists based on T140 analogs. Org Biomol Chem (2006) 4:2354-7. doi:10.1039/b603818b
Conflict of Interest Statement: The author declares that the research was conducted in the absence of any commercial or financial relationships that could be construed as a potential conflict of interest.

Received: 12 December 2014; paper pending published: 29 January 2015; accepted: 18 May 2015; published online: 08 June 2015.

Citation: De Clercq E (2015) AMD3100/CXCR4 inhibitor. Front. Immunol. 6:276. doi: 10.3389/fimmu.2015.00276
This article was submitted to Chemoattractants, a section of the journal Frontiers in Immunology.

Copyright (C) 2015 De Clercq. This is an open-access article distributed under the terms of the Creative Commons Attribution License (CC BY). The use, distribution or reproduction in other forums is permitted, provided the original author(s) or licensor are credited and that the original publication in this journal is cited, in accordance with accepted academic practice. No use, distribution or reproduction is permitted which does not comply with these terms. 